Regular Research Article

\title{
Forestry, illegibility and illegality in Omkoi, Northwest Thailand ${ }^{1}$
}

\author{
Bobby Anderson ${ }^{1,2, *}$ and Patamawadee Jongruck \\ 1 Bobby Anderson is a Myanmar-based Research Associate at the School of Oriental and African Studies, \\ University of London. Email : rubashov@yahoo.com \\ 2 Professor Patamawadee “Jan" Jongruck teaches at Chiang Mai University's School of Political Science \\ and Public Administration. Email : patamawadee.j@cmu.ac.th \\ * Corresponding author
}

\begin{abstract}
Opium poppy cultivation in Thailand fell from 12,112 hectares in 1961 to 281 ha in 2015. One outlier exists: Chiang Mai province's remote southwestern district, Omkoi. $90 \%$ of the district is a national forest reserve where human habitation is illegal. However, an ethnic Karen population has lived there since long before the law that outlawed them was created, unconnected to the state by road, with limited or no access to health, education and other services: they cultivate the majority of Thailand's known opium poppy, because they have little other choice. They increasingly rely on cash-based markets, their lack of citizenship precludes them from land tenure which might incentivize them to grow alternate crops, and their statelessness precludes them from services and protections. Nor is the Thai state the singular Leviathan that states are often assumed to be; it is a collection of networks with divergent interests, of whom one of the most powerful, the Royal Forestry Department, has purposely made Omkoi's population illegible to the state, and has consistently blocked the attempts of other state actors to complexify this state space beyond the simplicity of its forest. These factors make short-term, high-yield, high value, imperishable opium the most logical economic choice for poor Karen farmers residing in this "non-state" space.
\end{abstract}

Keywords: Alternative Development, Drug Control, Forestry, Hill Tribes, Karen, Swiddening, Zomia

\section{Introduction}

Thailand's opium poppy cultivation fell from 12,112 hectares (ha) in 1961 to 281 ha in 2015. By most standards of measurement, the country's "war" on drug production succeeded, especially in comparison to other drug-producing countries such as Afghanistan, Myanmar ${ }^{2}$, Laos, Colombia, Peru, Bolivia and Mexico. The United Nations Office on Drugs and Crime (UNODC) declared Thailand "opium free" a decade ago, and has not included Thailand in its World Drugs Report since 2008. Thailand is also widely heralded as a successful example of "alternative development" programming, which seeks to replace illicit crops with licit ones, and which is conducted in tandem with coercive policies to eliminate the opium economy, comprised of poppy cultivation, refinement into opium, conversion to heroin, and export.

One outlier exists: Chiang Mai province's remote southwestern district, Omkoi, where the majority of known opium cultivation in Thailand occurs. $90 \%$ of Omkoi is classified as a national forest C-Zone reserve area: people are prohibited from inhabiting, cultivating or otherwise utilizing it. But a large ethnic Karen population of swidden cultivators has lived there since long before the law that outlawed them was created. They reside in areas unconnected to the state by road, with

\footnotetext{
1 This article is the second of a two-part series for Forestry and Society; the first, "People, Land and Poppy: the Political Ecology of Opium and the Historical Impact of Alternative Development in Northwest Thailand", was published in Forest and Society 1/1, April 2017.

${ }^{2}$ For the sake of continuity this article uses the country names Thailand and Myanmar throughout, including in pre-1939 Instances when Thailand's official name was Siam, and in pre-1989 instances when Myanmar's official name was Burma.
} 
limited or no access to schools, health centers, and other services: select among them are the grassroots cultivators of Omkoi's opium supply, sold onward to opaque networks the state is struggling to identify. While most Karen no longer engage in cultivation or consumption-indeed, most have been incorporated into the Thai state as well as Thai culture-in remoter parts of Omkoi, Karen cultivation rates are the highest in Thailand. Thai and US drug control efforts historically overlooked this district, and possibly others hosting drug production not yet identified by the state, because it did not host an interrelated communist insurgency, nor were cultivation rates as high as other areas of NW Thailand.

Opium's profit hardly accrues to the farmer. Those in Omkoi who grow opium do so because they have little other choice. The encroachment of "development" upon Omkoi's Karen has already occurred through their growing reliance on lowland markets where currency is the only form of exchange, and opium is the highest-value cash crop around. A lack of citizenship precludes much of the rural population from land tenure which might incentivize the growing of estate crops with a lower rate of return and a longer cultivation period. Their statelessness also precludes them from services, credit and other protections. Even if they had citizenship, their presence in a C-Zone reserve area still renders them "illegal". And if these issues are all overcome, a stark truth remains: there is no alternative crop that can equal the price a farmer earns from opium. Previous programs did not succeed because of agriculture, but because of the increased presence of the state.

Nor, in the case of Omkoi's Karen, is the state the Leviathan it is assumed to be; it is a set of agencies and networks of divergent and contradictory interests, and this hobbles the state's alternate development approach. Omkoi's complexity has been simplified by state actors around environmental concerns, but the attempts of other state actors to make Omkoi's inhabitants legible leads to contradictions. For example, forestry officials refuse to allow the General Administration Department (GAD) to gazette settlements and provide services, and state extension agents cannot provide substitute crops which require land clearance or supporting infrastructure; in a reversal of "classic" statebuilding practice as described by Anderson (2006), Scott (1998), Tilly $(1985,1990)$ and others, this government department purposely makes a population illegible. These factors serve to make short-term, high-yield, high value, easily transportable and imperishable opium the most logical choice for poor farmers, especially given the lack of law enforcement presence.

That presence, however, is growing, most palpably in eradication and law enforcement. Omkoi has already been bureaucratically constructed-the state certainly doesn't see it as stateless-but the complex realities on the ground do not match the deliberately simplified prisms through which Omkoi is viewed. The district hosts the historical extension of lowland Padi state power into an ungoverned, untallied, ephemeral highland (Scott 2009)-one of the last areas in Thailand to undergo this process. As the government destroys opium poppy but does not replace it with alternates, the potential for future unrest cannot be discounted. However, a middle ground between the state's contradictory positions can be discerned.

This analysis seeks to discover how the state can reduce opium cultivation and preserve the watershed whilst legitimating both Omkoi's people and the Thai state, as well as the recent historical circumstances in which Omkoi was "forgotten" by the state in the first place. It is based on field research and interviews with Thai government officials, Karen leaders, security actors, academics, civil society representatives, local businesspersons, ex-cultivators, and recovering opium addicts in Omkoi, Chiang Mai, and other areas, from December 2015 to June 2017. These findings emerged from an earlier project at the National University of Singapore's Lee Kuan Yew School of Public Policy, in collaboration with Chiang Mai University and the Government of Thailand's Office of the Narcotics Control Board.

\section{Contemporary Opium Poppy Cultivation in Northwest Thailand}

Omkoi lies 170 kilometers (a four hour drive) from Chiang Mai town, in the far southwest of the province near the Myanmar border, which is as porous as it is under-patrolled ${ }^{3}$. Of the $281 \mathrm{Ha}$

\footnotetext{
${ }^{3}$ While select interviewees state that the border is well-patrolled, the majority of them state otherwise.
} 
of opium poppy uncovered by Thai authorities in 2015, $142 \mathrm{Ha}$ occurred there. This was a significant decline from the $246.37 \mathrm{Ha}$ identified in the previous year; in 2016, however, The Thai Office of the Narcotics Control Board (ONCB)'s surveillance revealed the highest cultivation identified since 2009. The price of a Joi (1.6 Kilos) of opium in Omkoi fluctuates between 120,000 and 170,000 Baht (US\$3,650 - US\$5,170); despite government assertions that Omkoi's opium is only for internal markets, these fluctuations causally match international demand fluctuations. Opium usage in Omkoi is also prevalent. The Chiang Mai University Medical Faculty's substance abuse research center estimates that Omkoi hosts 5,000 addicts, but their estimate is based on an arbitrarily assigned average of 5-10 addicts per village. No one knows the level of addiction in Omkoi, although anecdotally it is high. Omkoi's six sub-districts contain roughly 100 villages, although no agreed-upon figure exists: many of the "villages" are only a set of homes populated by a single extended family. Omkoi's population is estimated at 55,000; each government agency has a different population figure ${ }^{4}$. Most of Omkoi is inaccessible during the rainy season; beyond select main roads, the district lacks schools, medical facilities, roads and electrification, due to its national forest status (see below). Beyond the sub-district capitals, the area lacks government presence, and according to government interviewees, Omkoi serves as a place of exile for incompetent civil servants who are often absent from their duty stations ${ }^{5}$. The lack of educational opportunities in Omkoi over generations results in a waiver of the civil servant prerequisite of a secondary school diploma; in Omkoi, civil servants only need to speak Thai.

Approximately $80 \%$ of Omkoi residents are non-Thai hill tribes that still practice swiddening-mostly highland Karen with family links to Myanmar. Anecdotally, most of the indigenous population living in the remotest areas of Omkoi lack Thai citizenship (UNESCO, 2010); the further one travels from a road in the district, the less Thai citizens one encounters, even though nearly all Omkoi's Karen have lived in Thailand for generations.

\subsection{The Karen in Southeast Asia}

Contemporary issues of cultivation in Omkoi involve Karen in particular. In 1983 Peter Hinton wrote "Why the Karen do not Grow Opium: Competition and Contradiction in the Highlands of North Thailand", and this assertion continues to be made. But interviews with ONCB, academics, and Karen informants indicates that in particular areas of the highlands, they do grow opium, and they did in 1983. In Chiang Mai's Nong Tao, a village in the Mae Wang River basin, for example, Karen began growing opium a century before, after it was introduced by Hmong migrants from China ${ }^{6}$ who planted poppy on hillsides cleared of teak. In Omkoi Karen have been growing opium for at least 50 years.

Southeast Asia's Karen predominantly reside in Myanmar; roughly half a million live in Thailand (Delang, 2003), although Karen interviewees state a population of close to 1 million. Thailand's Karen are generally concentrated along the Western border with Myanmar, from Mae Hong Son to Ratchaburi and Petchaburi. Chiang Mai Province contains one-third of Thailand's Karen. Sgaw are the largest Karen language sub-group, followed by Pwo (alt: Po). Two much smaller groups exist: Dtawng Soo/ Pa'o and Kaya/ Baway. Karen historically reside at elevations ranging from 600 to 1,000 meters $^{7}$, in small villages often comprised of extended family units of between 10 and 200 households. These village units were historically ephemeral, with villages subdividing constantly; entire villages would move as fields are planted, harvested for a few seasons, and then left fallow. The latter half of the $20^{\text {th }}$ century has seen ever-larger numbers of Thailand's Karen move from the hills to valleys and cities, especially youth.

\footnotetext{
4 Interview, CMU Professors/ ONCB, Chiang Mai, December 2015.

${ }^{5}$ Interviews, ONCB, Chiang Mai, December 2015.

6 Interview, Karen leader Phaw Luang Jorni Odochao, June 23, 2016.

7 In Myanmar, lowland Karen populations are found in delta areas that were once malarial forests and swamps prior to the British relocation of the capital from Mandalay to Yangon. Delta Karen allied with the British and against the Bamar who were their oppressors; against the historical norm, they did not flee, and Karen communities remain in the Ayeyarwady, although many no longer speak Karen.
} 
The Karen identity appears to signify the external peoples and modes of governance which Karen wish to distinguish themselves from, rather than what Karen are in the absence of the other. The identity was promoted in early $20^{\text {th }}$ century Myanmar by British officials, in order to simplify their census (Cheesman, 2002), and by missionaries who midwifed Karen nationalism. Cheesman, Scott, and other scholars note that the Karen, when viewed as a whole, share no common language, culture, history, or religious belief: their languages are not mutually intelligible. Their religions include Buddhism, Catholicism, and various Protestant sects; some are purely animist, while elements of animism are also found in Karen practices of other religions. The delineation between Karen sub-groups is unclear, as is their delineation from other non-Karen groups such as Kachin and Shan. Although all identities, including Han and Thai, are constructed, the Karen and numerous other highland tribes are stark recent examples of the ephemeral nature of ethnicity; Leach (1954), Scott (2009) and others note that highlanders have switched identities from Kachin to Shan within two generations, and multiple ethnicities can simultaneously occur in individuals. The same person can be a Kachin in one town, a Shan in another. In contemporary Chiang Mai province, a Karen in Omkoi becomes a Thai in Chiang Mai town, and these mimicries solidify into identities over time.

Thailand's Karen are, by and large, integrated into the Thai state to a greater degree than Hmong, Lisu and others; Hanks et al (2001) notes that they were not even considered to be a "hill tribe" by select authorities, although they were still considered to be non-Thai. Forsyth and Walker (2008) note the generalization of Karen by Thai authorities as "protectors" of the forest, in stark contrast to "destroyers" such as Hmong ${ }^{8}$. Karen traditionally cultivated opium for their own use, rather than for wider markets. The depth of this tradition amongst Karen is disputed by scholars as well as interviewees: nearly all agree that at in the last 50 to 100 years, opium was introduced by Hmong and integrated into Karen animist and other cultural practices, or simply used as a way to pass the time'.

While most Karen no longer engage in cultivation or consumption, in remoter parts of Omkoi their cultivation rates are the highest in Thailand. Omkoi's Karen, then, are not only peripheral to Thais; they are generally peripheral to other, more integrated Karen.

While James C. Scott's research on Zomia (2009) is pivotal to analysis of Omkoi's recent history and in explaining the different strategies/ practices Omkoi Karen and other highlanders historically adopted to evade state control, the model has its limits when it is used as a prism through which to view contemporary Omkoi. Scott himself states that Zomia has not really existed since the end of the Second World War; it is anachronistic as per its intention. The Framework developed by Forsyth and Walker in Forest Guardians, Forest Destroyers: The Politics of Environmental Knowledge in Northern Thailand (2008) provides more clarity to Omkoi: their work demonstrates how the state uses environmental narratives to consolidate control over the land, resources, and people (Forsyth \& Walker, 2008: 231), and of how environmental and security concerns are conflated, in border areas in particular; these prisms are being used in order to cast Omkoi as symptomatic of a crisis that must be solved to legitimate the state. Scott's earlier work, in Seeing Like a State (1998), is also broadly supportive of Forsyth and Walker in that it describes the narrowing of the vision of state officials as an aid to control (Scott, 1998, 11); something particularly obvious in the simplification in which state actors view Omkoi, where the area's complexity is reduced to manageable dimensions by state actors (ibid. 22).

\subsection{Omkoi's Forest}

"Utilitarian discourse replaces the term "nature" with the term "natural resources"... plants that are valued become "crops", the species that compete with them are stigmatized as "weeds", and the insects that ingest them are stigmatized as pests. Thus, trees that are valued become "timber",

\footnotetext{
8 This dichotomy was most obvious in the Chom Thong upland - lowland dispute (Puginier 2003).

9 Interviews, villagers, CRSPO, ONCB, Mae Tuen/ Omkoi town, Omkoi, March 2016.
} 
whilst species that compete with them become "trash trees" or "underbrush". The same logic applies to fauna. Highly valued animals become "game" or "livestock," while those animals that compete with or prey upon them become "predators" or "varmints."

- James C. Scott

Seeing Like a State, p. 13

"...In national forests that the authorities declare to be reserved or restricted, people have long been there. It is strange to enforce the law against people who live in such areas, which have always been non-reserved, but only lately declared reserved because of some lines drawn on paper. The problem occurs when those boundaries are drawn, causing the people inhabiting those areas to become "lawbreakers". In terms of legislation, they may be seen to violate the law, because the law is legally passed. However, if we consider the issue naturally as to who is actually breaking the law, it becomes clear that the lawmakers are, because the people lived in the area long before the law was enacted."

- King Bhumibol Adulyadej

June 27, 1973

Thailand's rapid population increase and explosive rates of economic growth and accompanying development between 1960 and 2006 resulted in a reduction of forest from $53.33 \%$ to $30.92 \%$ of overall land area (Ongprasert, 2011). The Royal Forestry Department (RFD) is tasked to enforce C-Zone regulations in Thailand. It was initially created to protect and regulate Thailand's teak supply in the late 1800s, after highland Karen began "illegally" selling teak to the British in Shan and the French in Laos. Ironically, RFD can be historically implicated in the introduction of opium to Karen: they banned Karen from growing rice, which would have required large-scale forest clearing, but allowed them to grow opium, which required much less clearing. The Karen would trade the opium for the rice they were prohibited from growing directly; the government taxed the trade as well.

Catastrophic flash floods in Thailand in 1989, widely linked to deforestation, led to enhancements in RFD's mandate, and soon subcontracted Thai demand for forest products into Myanmar (Smith, 1994), Karen National Union areas in particular ${ }^{10}$, while Thailand's own watershed areas were preserved. Since its inception, the RFD has been at loggerheads with hill tribes, denouncing and seeking to end swiddening, which it and other agencies uniformly oppose under the mistaken impression that it is environmentally harmful, while many available studies demonstrate that it is, traditionally, a rejuvenating practice (Asia Indigenous People's Alliance, 2012; Bruun et al., 2009; Erni, 2009; Laungaramsri, 2005). The Department of National Parks, Wildlife and Plant Conversation (DNP) has been hived off from the RFD but they have the same policies and the same regard for highlanders as their parent department. Both agencies are reportedly corrupt (Phromlah, 2013).

RFD agents continually encroach upon rights recognized by Thai authorities, such as gathering fallen wood to use in cooking fires. Whilst ad-hoc actions to defend such rights occur regularly, according to interviewees, a broader movement to guarantee hill tribe rights to engage in traditional practices has not yet emerged. In the mid-1990s the Northern Farmer's Alliance, comprised of both highlanders and Thais, had promise, and the alliance organized a march from Nong Tao to Bangkok to protest the expulsion of Karen from Gampong Kit, state their rights over the forest and decry RFD abuses; in Bangkok, they were able to meet the RFD minister "for five minutes". According to interviewees in Nong Tao, this was the pinnacle of Karen participation in

\footnotetext{
10 Interview, KNU representative U Mam Char, Taung Galay, Kayin State, Myanmar, December 2016. The KNU has recently declared a moratorium on forestry in its areas, and signed an MoU with the World Wildlife Foundation (Irrawaddy 2016).
} 
civil society, and was followed by a fall in alliance members ${ }^{11}$. The last Karen community rights activist of note, Porlajee "Billy" Rakchongcharoen, was illegally detained by RFD officers in Kaeng Krachan National Park, Phetchaburi, on April 17, 2014, on the orders of then- park superintendent Chaiwat Limlikitaksorn, who had ordered a Karen village burned in 2011. Billy was never seen again $^{12}$. The RFD continues to blame highlanders for lowland disasters, including the 2011 floods and a 2015 epidemic of lowland haze.

RFD has been instrumental in the configuration of Omkoi within the state as a C-zone forest reserve ${ }^{13}$ : their prism through which they view the reserve prevents much of the population from state protection in the form of citizenship. While in most cases states seek legibility of populations, in Omkoi's case, the RFD purposely keeps populations illegible. And while Karen have traditionally found themselves regarded by the state as protectors, especially vis a vis Hmong, in contemporary Omkoi they are labeled the destroyers. Omkoi's watershed status can also be viewed as political in that it intends only to protect downstream (Thai) users; the designation is "a function of wider value judgements about the appropriate use of the uplands, the purpose of environmental management, and the status of different speakers" (Forsyth \& Walker, 2008, 231).

\subsection{A Topography of "Criminality"}

In 2009, ONCB realized that much of the opium seized by authorities was originating in Omkoi. This occurred after roughly a decade where no cultivation surveys were undertaken in the district, theoretically because cultivation was thought to have ended ${ }^{14}$. Whether cultivation had ended at that time only to re-start later is, in hindsight, questionable: ONCB data reveal significant cultivation from at least 1995 to 2000, including a 485\% increase in hectares under cultivation between 1997 and 1998. This increase in cultivation demonstrates Omkoi's connection to international markets; in the same year in Afghanistan, Taliban leader Mullah Omar issued a fatwa declaring that opium poppy cultivation and heroin manufacture was un-Islamic (Rashid, 2000). The price of heroin soon doubled in New York City, and nearly two decades ago unknown persons in Omkoi responded to opportunity.

In order to conquer a place, one must first map its people (Anderson, 2006; Scott, 1998; Scott, 2009; Winichakul, 1994). This is doubly true when a stateless area's resources are utilized by a stateless people in a manner different from what the state intends; contestations over resources are implicit challenges to legitimacy ${ }^{15}$. In Omkoi this is the continuing process of conversion of highland economies and highland cultures-which cannot be disentangled from one another-to serve lowland needs. Thailand's priority is security, and so it seeks the contours of a topography of crime. The Thai state does not know the identities of stakeholders in Omkoi's opium economy. But this is changing. ONCB has identified a network constituted of financial sponsors (some of them non-resident Thai businesspersons operating in partnership with Karen leaders) and local government officials, both Thai and Karen. The former encourages cultivation and purchases the crop, while the latter is either directly involved in the trade or accepts bribes to let it continue.

\footnotetext{
11 Protests, interviewees note, are not easy to sustain over time, especially when "people have families and need to work" (interview with Jowalu "Oshi" Chindanai, Nong Tao, June 23, 2016.

${ }^{12}$ In May 2015 Chaiwat was appointed by the DNP to head the Tiger Corps Operation Unit, a forest and wildlife protection unit. He remains the only suspect in Billy's disappearance.

13 Various forest management initiatives also occur in C-zone designated areas, including the establishment of protected areas such as watershed areas, national parks, wildlife sanctuaries (Omkoi contains Thailand's last populations of wild elephant and mountain goat), non-hunting areas, forest parks, biosphere reserves, botanical gardens, and arboreta.

14 The sudden end of surveillance in Omkoi in 2000/ 2001 makes little sense when one considers that $185.92 \mathrm{Ha}$ of opium poppy was identified there in the 1999/2000 season.

${ }^{15}$ The inverse can also be found. Indonesia's annexation of Dutch New Guinea (later renamed Irian Jaya, followed by Papua) was initially contested by an insurgency that fragmented across decades. Vast tracts of the territory are not contested and in those areas the state concentrates on resource extraction; when people pose no threat, they are provided with no services, and in many areas, aren't even counted (Anderson 2015).
} 
Many sponsors are anecdotally local politicians who finance electoral campaigns with opium earnings ${ }^{16}$. Of 305 local leaders and civil servants in Omkoi, ONCB has initially identified 50 involved in the trade: this number will likely rise.

Anecdotally, in the vacuum of the state found in Omkoi much crime exists besides opium poppy cultivation: stolen-to-order motorcycles and cars flow toward Myanmar, and trafficked people emerge from there, destined for Thai farms, fishing boats, and brothels. Ivory trading and illegal logging also occur. In this Omkoi's isolation is convenient, even purposeful: according to one ONCB director, the government "intentionally makes Omkoi a forgotten place." And although interviewed government officials claim that Omkoi is a place of exile for incompetent civil servants, it is more plausible that particularly corrupt civil servants seek postings there, and likely pay a commission to the relevant human resource office to secure a placement in such a profitable district.

\section{A Network Governance Approach}

The Royal Thai Government created the multi-agency Centre for the Resolution of Security Problems in Omkoi (CRSPO) in 2012, mandated to suppress opium cultivation, human trafficking, and illegal logging ${ }^{17}$. As the CRSPO has more clearly discerned the complexity of the area, it has expanded beyond its initial security focus, moving beyond eradication and into alternative development and harm reduction. The ministries and departments represented in the CRSPO increased to 22 in December 2015, and now include education and health. It includes ONCB, which plays an overall coordination and eradication targeting role, and the Highland Research and Development Centre (HRDI), which introduces replacement crops and provides extension services to farmers in eradication areas. It also includes the Royal Forestry Department, the presence of which lays bare core paradoxes in the approaches of different state actors. The CRSPO has no hill tribe representation, civil society or otherwise: Karen and other voices are not contributing to the policies which the paternalistic state which regards them as nak anurak is using to shape their futures.

\subsection{Alternative Livelihoods}

HRDI began providing extension services in Omkoi in 2009. Their contemporary alternative livelihoods model, antithetical to highland traditions of swiddening and mobility, provides Omkoi cultivators with a geographically fixed short-term alternate livelihood while preparing them for a longer term one, generally an estate crop with a 3-5 year cultivation period before first harvest. This can include non-agricultural alternatives such as vocational and technical trainings. But this "Royal Project Extension" is less successful than its predecessors elsewhere in the Northwest. Firstly, while the project is implemented by HRDI, it is not officially the Royal Project, and therefore, it does not carry royal authority. The Royal Project, by law, supersedes other laws, most importantly RFD regulations (see below); the extension does not. Secondly, the Royal Project does not serve as a guaranteed, fixed-price purchaser of new substitute crops in Omkoi, as it does in other areas (Anderson 2017). Short-term crops such as cabbage, decorative flowers and lettuce provide quick returns on investment, but these crops are generally not travel-worthy. Good roads were an important success factor in historical alternative development (Renard, 2001); they ensured that produce arrived in markets in a sellable condition, and they keep costs down, but good roads in Omkoi are scarce. The state-resistant areas where substitute crops are most needed are those same areas where ruined (or no) roads would most damage crops transported to market.

\footnotetext{
${ }^{16}$ ONCB interviews, Chiang Mai, December 2015.

17 Interview, $7^{\text {rd }}$ Infantry Colonel and CRSPO Secretary, Chiang Mai, June 21, 2016. While Mae Sot is the primary entry point into Thailand for smuggled persons and illicit/untaxed/ illegal goods including gemstones, logs and drugs (BBC 2001), due to its less rugged geography, state pressures on the illicit traffic crossing the Salween River result in places like Omkoi acting as secondary conduits.
} 
Omkoi's licit crop cultivators are open to other forms of abuse: farmers lack vehicles, and are often taken advantage of by middlemen with the means of transport who fix prices and reap the benefit at lowland markets ${ }^{18}$. Less-duplicitous middlemen would need to pay low costs to the farmer in order to compensate for the percentage of the crop which will be lost in transport. Other Omkoi farmers are caught in an exploitative contract-farming model, with fixed prices far below the costs accrued through cultivation and maintenance. In the remotest areas, crop substitution is diversified subsistence. Even without exploitation, the remoteness of the area means that the costs of business will be high. Alternative development remains constrained by a lack of land tenure: homes and plots in the C-Zone forest reserve will not be legalized. Cultivators have little reason to switch to legal crops such as Arabica that they will still cultivate illegally for less income over a longer time frame. A further impediment to land tenure is the inability of many Karen to prove Thai citizenship. Land tenure is believed by RFD to be antithetical to watershed preservation. These factors serve to make short-term, high-yield, high value, easily transportable and imperishable opium the most logical choice for those poor farmers rendered illegible by the state, especially given the lack of law enforcement presence.

The state's alternative development approaches are constrained by intra-state divisions which the state's Network Governance approach has yet to streamline (Jongruck, 2012, 2015): "State" is not a monolith. Personalities, networks, and interests shape the political ecology of opium in Omkoi. Omkoi's paradoxical designations amongst state actors results in varying degrees of legibility based on the priority of a given department. This leads to policies which serve to cancel one another out, and competing interests are most apparent in forestry policy. The Royal Forestry Department only grudgingly and occasionally acknowledge a human population, and they ignore the CRSPO, even though RFD is a member. RFD's mandate, captured in the 1964 National Forest Conservation Act, contradicts ONCB and HRDI cultivation reduction strategies, namely crop substitution, infrastructure, services, and the "legalization" of a long resident population in the watershed that RFD is tasked to keep free of human habitation. RFD has blocked HRDI attempts to build small infrastructure in support of livelihoods. RFD policy also makes the construction of roads in forest reserves difficult, if not impossible: the application process takes up to eight years ${ }^{19}$. Only recently the $3^{\text {rd }}$ Army forced the refurbishment of the $107 \mathrm{KM}$ Omkoi ring road, through the intersession of members of the military currently in power in Thailand and allies on the Privy Council, who forced RFD Bangkok to approve the request. RFD's prohibition of most road-building is not unfounded, however: road building enables illegal logging by facilitating access.

The Thai Department of Local Administration (DOLA), for its part, seeks to make Omkoi's population legible, and grant secure land titles: RFD prevents them from doing so. Despite the tenuous illegality of these settlements, it is unlikely that the Thai authorities will relocate Karen in the national forest to other areas. According to guidelines for relocation set by the Thai authorities in the 1970s, they must volunteer for relocation, and be relocated to a similar ecological zone at a similar elevation. Authorities have undertaken land exchanges where, in exchange for not swiddening a 50 ha upland area, they are provided with 5 ha of lowland rice padi land to cultivate. This approach has serious limitations: upland Karen areas are distinguished by a paucity of land and a scarcity of people, whilst lowlands are the inverse. There simply isn't enough lowland padi for upland cultivators. For those who do make the exchange, this is not simply a matter of livelihood; it is a matter of culture, and of incentivizing Omkoi Karen to be, in a sense, more Thai.

Despite these blockages, RFD are not actively seeking to evict Omkoi's Karen, and they allow the cultivation of crops which do not involve land clearance, namely coffee and avocados. They also haphazardly provide limited land use permits for Karen farmers. This is a foundation upon which to build, but whether or not this might lead to a modification of RFD policy, and a middle

\footnotetext{
${ }^{18}$ An interviewee noted that cabbages and tomatoes her village cultivated were purchased by Thai middlemen for as low as 1 baht per kilo; the introduction of Arabica caused a wholesale abandonment of other alternative crops, even though Arabica is also a buyer's market, with prices fixed at 20-25 Baht per kilo.

${ }^{19}$ Interview, ONCB and $3^{\text {rd }}$ Army Representatives, Omkoi, February 2016.
} 
ground arrived at through a Participatory Land Use Planning project, which "seeks to achieve a successful marriage of diverse land management perspectives in transparent and locally inclusive ways" (Forsyth \& Walker 2008, 245), is anyone's guess.

\subsection{Eradication}

Despite five years of eradication, opium cultivation continues, with little discernable impact on price; CRSPO activities are not impacting supply. Early 2016 interviews with ONCB officials in Omkoi reveal record numbers of fields under cultivation in Omkoi's far east and northwest.

Eradication occurs in a non-systematic manner, partially due to the state's inadequate but improving surveillance capability in its remoter corners: ONCB only knows the number of plots it identifies and destroys, not the total number of plots under cultivation. They also only report on the number of plots destroyed once, whereas the evasion strategies Karen cultivators have developed result in staggered crops which will sprout on those same plots destroyed by the army, weeks after they depart. Each planting cycle is roughly 3 months, but the annual opium-planting season is 8 months; several overlapping planting cycles occur. Other evasion strategies create even more difficulties. For example, Omkoi's main opium poppy cultivation areas are at least 2 to 3 hours by road ( 20 to $30 \mathrm{~km}$ ) from Omkoi's district center, followed by a hike. No roads lead directly to poppy fields, which lay far from settlements, and so no information connects cultivator to crop unless they are apprehended on site. Plots are purposefully kept small, averaging $.25 \mathrm{Ha}$. Cultivation occurs on steep slopes, difficult to detect from satellite imagery. There remain areas that the state cannot see, even with satellites. The friction of terrain remains as important now as it was in colonial times.

However, cultivation will ultimately decrease as both the state continues gathering complex information, and cultivators gain an understanding of the technology being deployed against them. In Baan Mae Long Luang village ${ }^{20}$ during a CRSPO meeting in February 2016, each village head denied opium was being cultivated in their area; the CRSPO representatives then demonstrated satellite technology, showing on a laptop computer the opium poppy plots in several areas surrounding the villages of the attendees. It was the first time they had seen such a demonstration; some appeared shaken.

\section{Rethinking policy priorities:}

Omkoi, as a "stateless" region with little available data, will likely experience new contestations around expanding administration and coercive authority. The following recommendations will hopefully inform future policy interventions:

a) Alternative Development and Markets: ONCB and HRDI should continue to concentrate on crops which do not require land clearance. Arabica coffee remains the ideal crop: it earns the highest value and travels the best on bad roads, unlike avocados or peaches. It requires some shade, so the watershed remains preserved, and RFD implicitly does not object to it. The prohibition on chemical fertilizer and pesticide in the watershed leaves open the possibility of internationally recognized organic certifications, a potentially lucrative opportunity. This is a process that HRDI could be instructed by the CRSPO to undertake on behalf of farmers. HRDI should robustly intercede with RFD to provide 20-40 year limited use permits for Omkoi farmers, specific to crops requiring shade. Citizenship should not be a pre-requisite for the issuance of such permits, but those seeking such permits should have to meet criteria established for long-term residency as part of a citizenship application process. HRDI should explore the possibility of banks recognizing these permits as collateral for credit to farmers. The CRSPO and ONCB should also concentrate on improving market linkages between farmers and larger coffee buyers that have reputational concerns over Fair Trade; existing middlemen need to be removed. Lastly, HRDI needs to establish a physical presence in the most severe opium-producing regions of Omkoi. This could involve contracting extension agents with the

\footnotetext{
20 This area was so afflicted by opium use that "even the monks needed treatment", according to ONCB.
} 
requisite knowledge of Arabica coffee, either from the $\mathrm{CMU}$ department of agriculture or from agriculture-focused NGOs.

b) Citizenship: The state should consider establishing a process by which residency and land tenure can be granted according to local testimony and committee investigation. Residency should include a citizenship pathway, subsidized by the state. In the case of DNA tests for children without birth certificates, the state should consider subsidizing these costly tests as well.

c) Indigenous rights, legalization and representation: the CRSPO should form a dedicated forestry sub-committee, co-chaired by RFD, ONCB and the army, and with Karen civil society representation and Karen testimony, to consider legalizing Karen villages known to pre-date the National Forest Conservation Act, with the stipulation that permanent land clearing be banned, that logging remain illegal except for the personal use of indigenous communities, and that no new construction occur (only refurbishment of existing structures) except for potential new health centers, schools, staff accommodation, and police stations. Road construction to existing settlements should be considered. The sub-committee will report to the CRSPO, which can then submit findings and recommendations to the national-level ONCB and army for them to intercede with relevant national-level actors in order to seek Omkoi-specific policy changes with the agreement of the national-level RFD, followed by instructions to provincial RFD.

\section{Conclusion:}

Under the auspices of a "war on drugs" and "alternative development", the highlands of Northwestern Thailand were, with a few exceptions, integrated into the Thai state starting in the 1960 's, through the extension of roads, the positioning of civil servants, and the extension of citizenship and services to hill tribes. The conversion of highland economies to fit lowland markets began long before this, and opium was the catalyst for that economic conversion; it was the first monocrop imported by outsiders, to feed lowland demand, and highlanders continue to be blamed for that mutation of sustainable agricultural practices by non-highland elites, KMT and otherwise, who reaped the profits from that trade. However, population growth in the last 70 years has consigned Zomia's methods of evasion, agricultural and otherwise, to history. This was, and remains, traumatic to hill tribes who have seen a way of life end; younger generations gravitate to Thai and other cultures.

This process of statebuilding within non-state spaces continues in Omkoi, an area bureaucratically constructed in different ways by different government departments with differing, and often, contradictory, priorities. For some, Omkoi's people are an inconvenience, and so they are not seen in favor of resources useful to the Thai state; for others, Omkoi's illegibility may provide profitable opportunities. The current and varying bureaucratic constructions of Omkoi within the state, however, have been recognized by government actors as untenable. The CRSPO's network governance approach provides the best platform by which to mitigate these contradictions and create a cross-department government policy that, if created equitably, makes Omkoi's people as legible as its trees. The state wishes to reconcile a current overriding forestry-focused policy that does not fit with facts on the ground in Omkoi, and ultimately it may do so by creating citizens of Omkoi's stateless peoples, with the same rights and access to services and protections as other Thais.

\section{Acknowledgements}

The authors extend their sincerest thanks to Tian Yeow Tan and Samuel Francis Woodcock, who participated in an earlier NUS study and conducted research with the authors in Omkoi and further afield. Micah Fisher at the University of Hawaii also provided valuable commentary. The author wishes to thank the Office of the Narcotics Control Board (ONCB) Region 5, especially Jerrapan Mugura, former ONCB Director of Strategy and Administration, and Karn Thaiyapirom. ONCB Region 5 representatives Director Watin Damronglaohapan, Director Pipop Chamnivikaipong, Thippamet Sangawanna, Kraivudh Maneeratana, and Varisara Yasamuth; 3rd Army 
representatives including Colonel Suraput Numlong, 7th Infantry Division; Professor Ora-orn Poocharoen, Dean of the Department of Political Science and Public Administration at Chiang Mai University, and Professor Panom; Raks Thai Foundation Program Coordinator Sarinthip Promrit; Pattana, Royal Project extension director; Khun Tuen Noi village inhabitants including village leader Pamoti; Bi Po village Tambon Administrative Officer Som Chai; Musa Bat Tam Village inhabitants including the treatment camp interviewees; Mimi Saeju Win of the Chiang Mai Lisu Cultural Heritage Center; Nong Tao Village Leader Phaw Luang Jorni Odochao, and Jowalu Oshi Chindanai. We also thank the Faculty and Staff at the National University of Singapore's Lee Kuan Yew School of Public Policy, as well as the two anonymous reviewers Any errors of fact or interpretation are the fault of the authors.

\section{Reference}

Anderson, B.O.G. (2006). Imagined Communities: Reflections on the Origin and Spread of Nationalism. London: Verso.

Anderson, B. (2015). Papua's Insecurity: State Failure in the Indonesian Periphery. East-West Center Policy Studies 73. Honolulu: EWC.

Anderson, B. (2017). People, Land and Poppy: the Political Ecology of Opium and the Historical Impact of Alternative Development in Northwest Thailand. Forest and Society, 1(1), 48-59. doi:http://dx.doi.org/10.24259/fs.v1i1.1495

Anderson, B., Tan, T.Y., Woodcock, S., and Jongruck, P. (2016). Thailand's Last Opium War: Governance and Illegality in a Highland Periphery. National University of Singapore Governance Study Project.

Asia Indigenous People's Alliance. (2012). Drivers of Deforestation? Facts to be considered regarding the impact of shifting cultivation in Asia. AIPP. http://ccmin.aippnet.org/attachments/article/956/Driver_\%20of_Deforestation.pdf, last accessed June 292016.

Bruun., ilde B., Andreas de N., Deborah, L., \& Alan D. Z. (2009). Environmental Consequences of the Demise in Swidden Cultivation in Southeast Asia: Carbon Storage and Soil Quality. Human Ecology 37; ASB-Indonesia Report Number 4, Bogor.

Cheesman, N. (2002). Seeing "Karen" in the Union of Myanmar. Asian Ethnicity 3(2), 199-220.

Delang., C. O. (ed). (2003). Living at the Edge of Thai Society: The Karen in the Highlands of Northern Thailand. London: Routledge.

Erni, C. (2009). Shifting the Blame? Southeast Asia's Indigenous Peoples and Shifting Cultivation in the Age of Climate Change. Paper presented at Adivasi/ST Communities in India: Development and Change", Delhi, August 27-29.

Forsyth., Tim., \& Andrew, W. (2008). Forest Guardians, Forest Destroyers: The Politics of Environmental Knowledge in Northern Thailand. Seattle: University of Washington Press.

Hanks., Jane, R., \& Lucien, H. (2001). Tribes of the North Thailand Frontier. Monograph 51, Yale Southeast Asia Studies.

Hinton, P. (1983). Why the Karen do not Grow Opium: Competition and Contradiction in the Highlands of North Thailand. Ethnology 22(1): 1-16.

Irrawaddy. (2016). KNU Signs Forestry Memorandum with WWF. November 9. http://www.irrawaddy.com/news/burma/knu-signs-forestry-memorandum-with-wwf.html, last accessed January 4, 2017.

Jongruck, P. (2012). Network Governance through Resource Dependence Theory: a Case Study of Illicit Drug Policy in Thailand. PhD dissertation, University of Manchester (UK).

Jongruck, P. (2015). "From Bureaucracy to (Mandated) Network: A Changing Approach to Opium Eradication in Northern Thailand". 15th International Research Society for Public Management Conference, University of Birmingham, United Kingdom, March 30 - April 1.

Laungaramsri, P. (2005). Swidden agriculture in Thailand. Myths, realities and challenges. Indigenous A airs 2/05. Copenhagen: IWGIA. 
Leach, E. (1954). Political Systems of Highland Burma: a Study of Kachin Social Structure. London: Anthlone Press.

Office of the Narcotics Control Board. 1995-2015. Opium Cultivation and Eradication Reports for Thailand.

Ongprasert, P. (2011). Forest Management in Thailand. Participants Reports on Forest Resources Management: 151.

Phromlah, W. (2013). A Systems Perspective on Forest Governance Failure in Thailand. GSTF International Journal of Law and Social Sciences 3/1, October.

Puginier, O. (2003). The Karen in Transition from Shifting Cultivation to Permanent FarmingTesting Tools for Participatory Land Use Planning at Local Level, in Delang, Claudio O. (ed). 2003. Living at the Edge of Thai Society: The Karen in the Highlands of Northern Thailand. London: Routledge, 183-210.

Rashid, A. (2000). Taliban: Militant Islam, Oil and Fundamentalism in Central Asia. New Haven: Yale University Press.

Renard, R. D. (2001). Opium Reduction in Thailand, 1970-2000. Chiang Mai: Silkworm Books.

Scott, J. C. (1998). Seeing Like a State: How Certain Schemes to Improve the Human Condition Have Failed. New Haven: Yale University Press.

Scott, J. C. (2009). The Art of Not Being Governed: an Anarchist History of Upland Southeast Asia. New York: Yale University Press.

Smith, M. (1991). Burma: Insurgency and the Politics of Ethnicity. London: Zed Press.

Tilly, C. (1985). War Making and State Making as Organized Crime, in Evans, Peter, Dietrich Rueschemeyer, and Theda Skocpol. Eds. Bringing the State Back In. Cambridge: Cambridge University Press.

Tilly, C. (1990). Coercion, Capital and European States, AD 990 - 1992. Hoboken: Wiley-Blackwell.

[UNESCO] United Nations Educational, Scientific and Cultural Organization. 2010. Highland $\begin{array}{llllll}\text { Household } & \text { Survey. } & \text { Last } & \text { assessed } & 7 & \text { Apr }\end{array}$ http://www.unescobkk.org/culture/diversity/livelihood/surveys/impacts-of-legal-status-onaccess-to-education/

[UNODC] United Nations Office on Drugs and Crime. 2007-2014. Southeast Asia Opium Surveys.

[UNODC] United Nations Office on Drugs and Crime. 2014. Last accessed May 2016. https://www.unodc.org/documents/southeastasiaandpacific//cbtx/cbtx_brief_EN.pdf

Winichakul, S. (1994). Siam Mapped: a History of the Geo-Body of a Nation. Honolulu: University of Hawaii Press. 